DOI https://doi.org/10.30525/978-9934-588-92-1-79

\title{
СУЧАСНИЙ СТАН ТА РИЗИКИ «ВЕЛИКОЇ ПРИВАТИЗАЦЇ̈ ТЮРЕМ» В УКРАЇНІ
}

\author{
Ніколаснко Т. Б. \\ доктор юридичних наук, дочент, \\ професор кафедри теорії права \\ та кримінально-процесуальної діяльності \\ Національної академії Державної прикордонної служби Украӥни \\ імені Богдана Хмельницького \\ м. Хмельницький, Україна
}

В умовах сьогодення, коли анасована ідея Міністерства юстиції України щодо великого розпродажу тюрем почала утілюватися у життя, в умовах всесвітньої пандемії COVID-19 постають питання доцільності та доречності такої ідеї, де сучасні виклики та реалії впливають не лише на Україну, але й на світ у цілому.

Ідея приватизації тюрем та переведення установ виконання покарань в Україні не є новою. Ще у 2014 році в межах Концепції реформування (розвитку) пенітенціарної системи України передбачалося будівництво нових установ виконання покарань за схемою державно-приватного партнерства [1]. Приватизації Лук'янівського СІЗО постала першим прикладом. За планом (умовами конкурсу) інвестор, який виграє торги отримує права власності на землю лише після інвестування коштів у будівництво нового СІЗО та здачу його в експлуатацію відповідно до міжнародних стандартів. Але, як показала практика, такі умови не задовільнили жодного інвестора. У чому ж питання?

Якщо поглянути на ідею приватизації з точки зору іiі доцільності, обгрунтованості задля досягнення належного рівня утримання засуджених, підвищення рівня досягнення ефективності ресоціалізації засуджених, покращення фінансування діяльності установ виконання покарань, то вона не викликає жодних заперечень. Але інвестувати кошти не у торгівельні центри, розважальні заклади, які приносять щоденні шалені прибутки, інвестори не готові. Отримати землі у центрі міста (як наприклад у Києві, Львові, Хмельницькому, де виправні установи (СІ3О) розташовані у самому їх серці) вони не проте, але витрачатися після приватизації омріяної ділянки, яка коштує чималих грошей (для прикладу вартість Лук'янівського СІЗО складала 70 млн 
доларів) на будівництво ще й додатково нових об'єктів (неприбуткових) інвестори не бажають.

Держава вирішила піти іншим шляхом. Як зазначив міністр юстиції Денис Малюська, оскільки у бюджеті немає коштів на в'язничну реформу, виходом із ситуації $\epsilon$ отримання фінансування шляхом упровадження платних камер, приватних СІЗО та розпродажу тюрем» [2]. При цьому фінансування розглядається 3 точки зору продажу земель уже сьогодні, а спрямування коштів на оновлення в'язничної інфраструктури протягом 10 років. Так, ідея щодо процедури продажу земель, яка складається із продажу нерухомості на відкритому аукціоні онлайн або через «Прозорро Продажі» із здійсненням розподілу коштів у межах балансової та понад балансової вартості є цікавою.

По-перше, кошти планується розподілити на дві частини. Одна частина - це кошти балансової вартості, які після продажу залишатимуться у спеціальному фонді Міністерстві юстиції, інша, направлятиметься до державного бюджету.

По-друге, кошти балансованої вартості планується спрямовувати на будівництво в'язничної інфраструктури, яка відповідатиме європейським стандартам [3].

По-третє, є пропозиції щодо врегулювання такої діяльності на законодавчому рівні. Так, проєктом Закону «Про внесення змін до Бюджетного кодексу України» № 3591 від 04.06.2020 р. народними депутатами було запропоновано у межах великого продажу тюрем унормувати питання зарахування до загального (30\%) та спеціального (70\%) фондів державного бюджету коштів одержаних від продажу тюрем. При цьому кошти із спеціального фонду державного бюджету мають бути спрямовані на проведення будівництва, реконструкції (реставрації) та капітальний ремонт об'єктів Державної кримінальновиконавчої служби України [4].

Але, як показав аналіз положень Бюджетного кодексу України, ці зміни поки що залишились на рівні пропозицій [5]. Крім того всесвітня пандемія COVID-19 радикально змінила ситуацію. Першочерговим постає потреба у забезпеченні безпеки засуджених/утримуваних та працівників ДКВС України в умовах коронавірусу; створення умов щодо ізолювання хворих чи контактних осіб у відповідних місцях; своєчасного та фахового надання належної медичної допомоги. Питання щодо створення нових об'єктів у таких умовах $\epsilon$ недоречними. До того ж збільшення видатків на боротьбу 3 пандемією, змусило переглянути видатки та витрати на фінансування зокрема Міністерства юстиції у тому числі і щодо приватизації. Зокрема планується кошти, які можуть бути отримані від великого розпродажу тюрем як об'єктів 
приватизації державного майна на погашення дефіциту бюджету. У таких умовах може виникнути ситуація, коли ідея, яке немає достатнього, чітко визначеного, вирішеного з урахуванням всіх ризиків проєкту може зазнати не лише краху, але й завдати неабияких збитків як самій державі, так і особам заради яких була ініційована така ідея.

Тому, запроваджуючи таку ідею насамперед необхідно:

- чітко визначити та вирішити на відповідному рівні порядок реалізації запланованої ідеї;

- врахувати можливі ризики у тому числі корупційні та шляхи їх вирішення;

- спланувати дорожню карту на короткострокову, середньострокову та довгострокову перспективи щодо забезпечення відповідно до міжнародних стандартів належних умов утримання ув'язнених, підвищення ефективності діяльності місць позбавлення волі, реконструкції та будівництва нових виправних установ тощо;

- узгодити план дій із зацікавленими структурами щодо реальності та ефективності його реалізації;

- залучити державний та приватний сектор у пенітенціарну систему у цілому, а не лише для будівництва нових тюрем;

- врахувати досвід інших країн світу, які мають позитивну практику щодо існування приватних тюрем.

\section{Література:}

1. Про схвалення Концепції реформування (розвитку) пенітенціарної системи України: розпорядження Кабінету Міністрів України від 13.09.2017 № 654-р. Урядовий кур’єр. 2017. № 178. URL: https://cutt.ly/dfqpifi (дата звернення 18.10.2020).

2. Малюська анонсував великий розпродаж в'язниць: стаття. URL: https://cutt.ly/igjlfuX (дата звернення 20.10.2020).

3. Малюська Д. Для розбудови в'язничної інфораструктури потрібно понад 10 років: стаття. Громадське радіо. URL: https://cutt.ly/tgjlP6L (дата звернення 18.10.2020)..

4. Проєкт Закону України «Про внесення змін до Бюджетного кодексу України» № 3591 від 04.06.2020. URL: https://cutt.ly/ $\operatorname{lghJCk1(дата~звернення~18.10.2020).~}$

5. Бюджетний кодекс України: Закон України від 08.07.2010 № 2456-VI URL: https://cutt.ly/dgjzSpb (дата звернення 18.10.2020). 